\title{
Community composition and status of avifaunal diversity in and around Ottu reservoir of Sirsa, Haryana, India
}

\author{
Deepak Rai* \\ Animal Behaviour and Wildlife Conservation Laboratory, Department of Zoology, Kurukshetra \\ University, Kurukshetra- 136119 (Haryana), India \\ Vanita \\ Animal Behaviour and Wildlife Conservation Laboratory, Department of Zoology, Kurukshetra \\ University, Kurukshetra- 136119 (Haryana), India \\ *Corresponding author. Email: drbkuk@gmail.com
}

\section{Article Info}

https://doi.org/10.31018/ jans.v13i2.2666

Received: April 1, 2021

Revised: May 23, 2021

Accepted: May 27, 2021

\section{How to Cite}

Rai, D. and Vanita (2021). Community composition and status of avifaunal diversity in and around Ottu reservoir of Sirsa, Haryana, India. Journal of Applied and Natural Science, 13(2), 593 - 606. https://doi.org/10.31018/jans.v13i2.2666

\begin{abstract}
Assessments of avian communities' composition in different habitats give an emphasis in monitoring environmental perspective. Depending on specific habitat functioning, their population pattern helps to determine the ecological health of an area. Bird surveys were accomplished on a fortnightly basis from October 2019 to September 2020 using Scan sampling, Point count and Line transect methods for evaluation of species abundance and richness in and around Ottu Reservoir, district Sirsa, Haryana (India). A total of 114 species comprising 91 genera, 47 families and 18 orders were recorded, among which 76 species were resident, 30 winter migrants and 8 summer migrants. Out of reported 114 species of birds, one species was vulnerable, 6 Nearthreatened as listed by IUCN. Three bird species were listed under Schedule-I and the remaining species under Schedule-IV of IWPA (1972); six species under appendices of CITES (2012). Species such as Rock dove Columba livia, Lesser Whistling-duck Dendrocygna javanica and Common Sandpiper Actitis hypoleucos with decreasing IUCN population trends were reported abundantly in the study area. Analysis of feeding guilds results revealed that Carnivores as predominated guild due to enriched food material. The presence of diverse plantation, aquatic body, serenity and agricultural fields serve the reservoir as potential habitat for residential and migratory species. Therefore, effective measures must be taken for the conservation of this area as a potential site for avian diversity.
\end{abstract}

Keywords: Avian communities, Ecological health, Passeriformes, Winter migrants, Ottu reservoir

\section{INTRODUCTION}

The avian population in different ecosystems has become an effective element in protecting biodiversity and determining appropriate conservation activities. Bird population estimation is important for understanding group structure, niche relationship, habitat preference and other behavioural aspects (Pawar et al., 2019). Birds are a structural part of entire planet, key species in sustaining ecological equilibrium and are needed for human sustenance similar to other biotic components (State of India's Birds, 2020). They serve as pointer species of a particular region (Blair, 1999); bioindicator for understanding environmental issues (Newton and Anim, 1995); demolish insect pests, scavenge carrions, pollinate flowers, bio-fertilizers, disperse seeds (Niemi,
1985; Padmavathy et al., 2010; Whelan et al., 2015) and alter the environment in way beneficial for other species. Wetlands sustain distinct communities of plants and animals, considering this habitat as a 'Biodiversity hotspot' within an area or landscape (Gopal and Sah, 1993). These serve as crucial habitat for wetland-dependent and water-associated birds representing breeding, feeding and roosting sites, vital for their conservation and management (James et al., 2001; Harisha and Hosetti, 2018; Vishwakarma et al., 2020). Avian species distribution patterns are determined by their mobility, habitat suitability, food availability, geo-physiological structure of wetland (Akosim et al., 2008).

India harbors 7,57,060 wetlands (with an area - 15.26 Mha) embracing 1,88,470 Inland (Natural and Man- 
made) wetland; 13,033 Coastal (Natural and Manmade) wetland and 5,55,557 wetlands (<2.25 ha). The state of Haryana has a total of 11,970 wetlands that covers an area of about 42,478 ha, accounting $0.86 \%$ of the state geographic area (National Wetland Atlas, 2011). Due to favourable environmental conditions, approximately 450 avian species had reported spending time for their necessities in this state (Goyal et al., 2014). Extensive work has been done by respective researchers (Gupta and Kaushik, 2013; Goyal et al., 2014; Chopra and Jakhar, 2016; Rai et al., 2017; Kumar and Sharma, 2018; Rai et al., 2019; Kumar and Sahu, 2020) in this state on distribution, ecology, diversity and conservation status of birds. Different wetlands of any site function as balancing reservoir to sustain the native biodiversity. The presence of diverse plantations, widespread agricultural fields in and around Ottu Reservoir, located in village Ottu, district Sirsa, Haryana endows appropriate habitat for avifaunal diversity. The reservoir serves as foraging, roosting, breeding grounds for resident species and stopover or wintering grounds for migratory species. Depending upon various conditions such as climate, habitat use and resources stability of a reservoir determines the presence of aerial foraging avifauna (Basu et al., 2018). The present study was conducted to fill the knowledge gap about the information on avifauna in Ottu Reservoir along with its ecological significance.

\section{MATERIALS AND METHODS}

\section{Study area}

The Ottu Reservoir is situated at district Sirsa, Haryana, with its geographical coordinates $29^{\circ} 29^{\prime} 39^{\prime \prime} \mathrm{N}$ and $74^{\circ}$ 54 '02"E, about $12 \mathrm{~km}$ west of Sirsa (Fig. 1 and 2). It is perennial lake that serves as a feeder for two Ghaggar canals (the northern and the southern canals) that carries water to adjoining areas and northern Rajasthan. It covers an area of about 950 acres with depth of approximately 15 feet (Goyal et al., 2014). The flow of lake is restricted by Ottu weir situated at $29^{\circ} 29^{\prime} 21^{\prime \prime} \mathrm{N}$ and $74^{\circ} 54^{\prime} 38^{\prime \prime E}$ near village Ottu (about 8 miles away from Sirsa) constructed in 1896-97 on Ghaggar-Hakra river of Haryana. The average annual rainfall of the district is approximately $325-400 \mathrm{~mm}$, with mean temperatures ranging from $4^{\circ} \mathrm{C}$ in winter to $48^{\circ} \mathrm{C}$ in summer (Goyal et al., 2016). The lake provides tremendous habitat due to diverse trees, bushes, aquatic vegetation, agricultural fields, floral species such as Eucalyptus spp. (Safeda), Azadirachta indica (Neem), Ficus benghalensis (Banyan), Acacia nilotica (Kikar), Ziziphus jujube (Jujube), Dalbergia sissoo (Shisham), Ficus religiosa (Peepal), Acacia arabica (Babool), Eichhornia (Water hyacinth) and attracts a large number of avian species considering as a suitable place for them.

\section{Methodology}

An ornithological survey was conducted periodically at selected study site from October 2019 to September 2020 in three respective phases viz., Morning, Noon and Evening phase. Data was recorded with the help of various methods such as Scan sampling (Altmann, 1974), Point and Line Transect (Gaston, 1975; Sutherland et al., 2005) and presented in the form of checklist of avian species. Bird's observation was made with binoculars and Canon Power shot SX50HS digital cameras, and identification was done with the help of field guides i.e., Grimmett et al. (2015); Arlott (2015); Grimmett and Inskipp (2019); Kalsi et al. (2019) and authenticated avian database (IUCN Red list of Threatened Species, Merlin bird ID and Oriental Bird Club image database). A checklist of recorded bird species was prepared and classified based on a common name, scientific name, alternative name, order, family and genus using Praveen et al. (2016), Praveen et al. (2019) and IUCN (2020). The assessment of Residential/Migratory status was done based on the presence or absence method (Grimmett and Inskipp, 2003; Kumar et al., 2016). The abundance status of species was calculated depending on the frequency of sightings and the definite criteria of Kumar and Gupta (2009), with some modifications. The criterion was quite different for both residential and migratory species. For residential species, abundance status was classified as Abundant (observed 16-21 times/21 visits), Common (11-15 times/21 visits), Fairly common (6-10 times/21 visits) and Rare (1-5 times/21 visits); whereas for migratory species the criteria varies for two selected seasons of one year field survey i.e., Winter (October-March) and Summer (April-September). In the winter season, the status is assigned as: Abundant (observed 9-11 times/11 visits), Common (6-8 times/11 visits), Fairly common (3-5 times/11 visits) and Rare (1-2 times/11 visits) and in Summer season: Abundant (observed 910 times/10 visits), Common (6-8 times/10 visits), Fairly common (3-5 times/10 visits) and Rare (1-2 times/10 visits). The IWPA (1972), CITES (2012), and IUCN (2020) were used to assess the conservation status and population trends (Increasing $\uparrow$, Decreasing $\downarrow$, Stable $\rightarrow$ and Unknown?) of the species. Feeding guilds were categorized into 8 guilds (Carnivore, Insectivore, Omnivore, Herbivore, Frugivore, Grainivore, Insecti/ Nectarivore and Piscivore) based on direct observation and literature (Ali and Ripley 1987; Grimmett et al., 1999; Singh et al., 2020). The relative diversity (RDi) value of the families was calculated formula given by La Torre-Cuadros et al. (2007):

$$
\mathrm{RDi}=\frac{\text { Number of bird species in a family }}{\text { Total number of bird species }} \times 100
$$




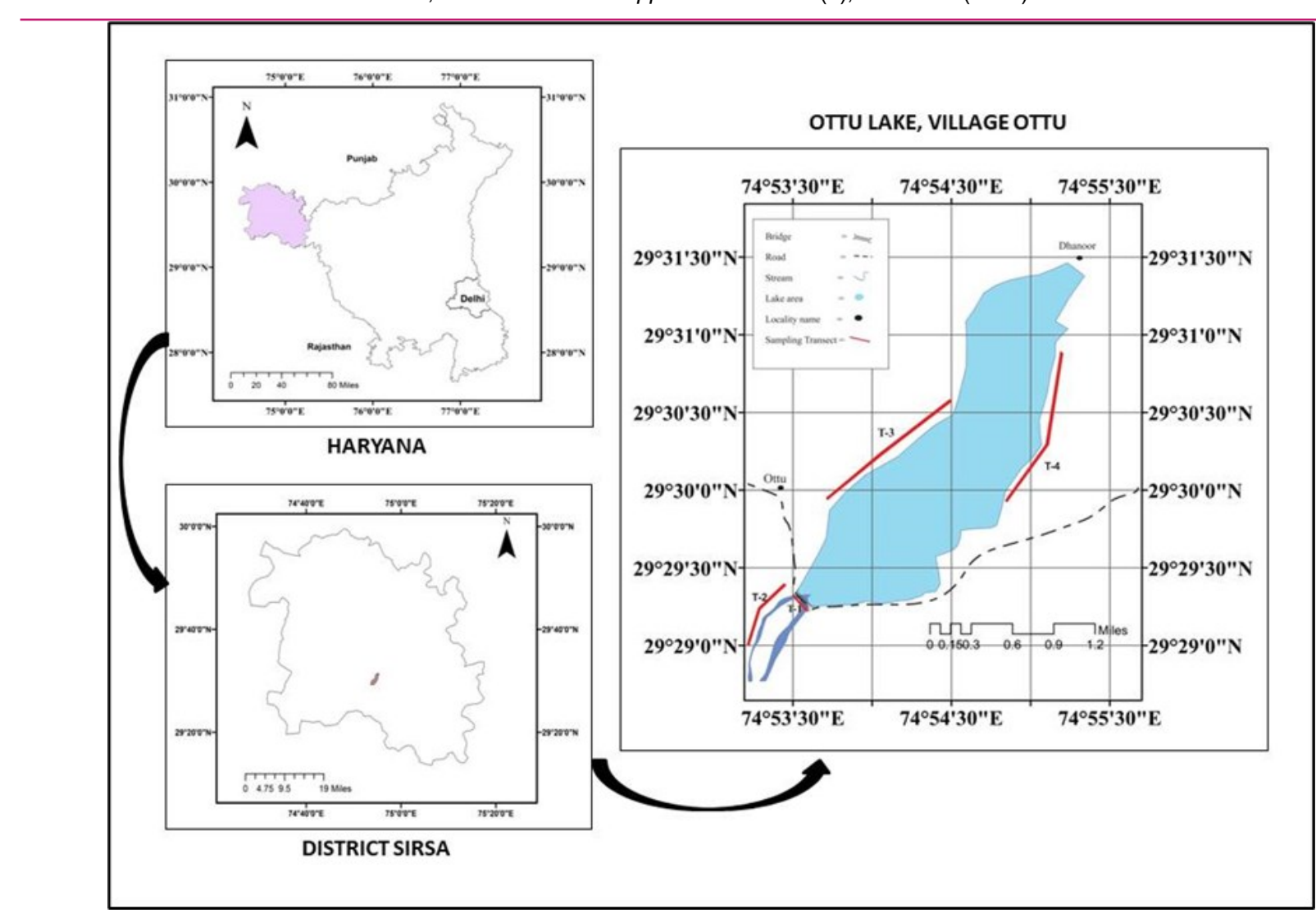

Fig. 1. Location and map of Ottu reservoir, Sirsa, Haryana, India.

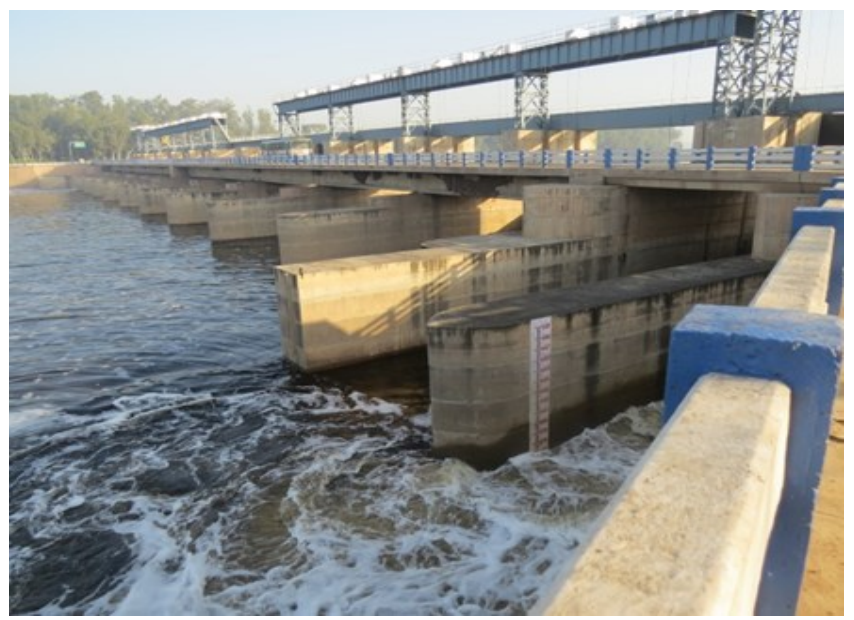

Fig. 2. Pictorial view of Ottu reservoir, Sirsa, Haryana, India.

\section{RESULTS AND DISCUSSION}

A total of 114 species belonging 18 orders, 47 families and 91 genera (Table 1) were recorded from Ottu Reservoir, district Sirsa, Haryana during 21 periodic visits from October 2019 to September 2020. Due to the outbreak of COVID-19, periodic field visits from 26 March 2020 to 30 April 2020 were missed. During the present study maximum number of recorded bird species belonged to Order Passeriformes (41 species in 20 families) followed by Charadriiformes (17 species in six families); Pelecaniformes (12 species in two families); Anseriformes (9 species in single family); Coraciformes

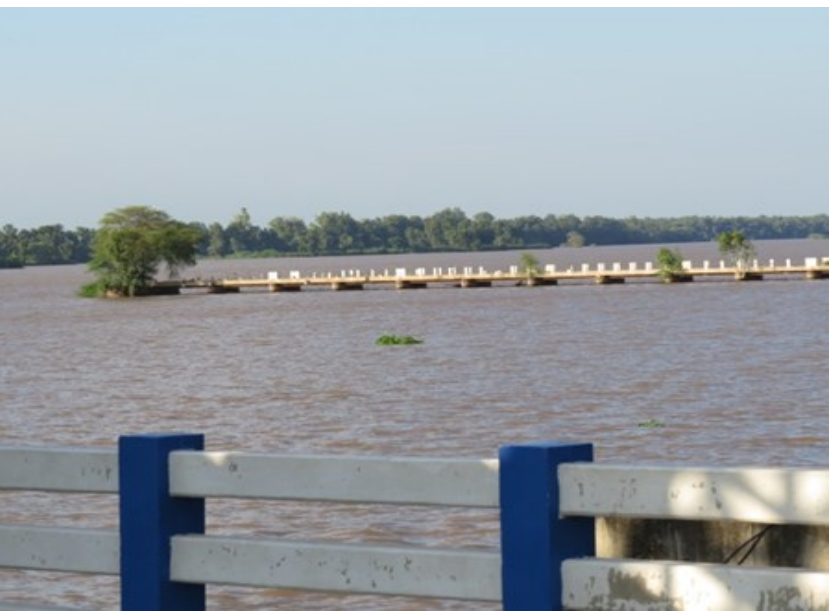

( 5 species in three families); Columbiformes ( 5 species in single family); Cuculiformes and Gruiformes (each with four species in single family); Piciformes (three species in two families); Bucerotiformes (two species in two families); Accipitriformes, Ciconiiformes, Psittaciformes and Suliformes (each with two species in single family) Galliformes, Phoenicopteriformes, Strigiformes, Podicipediformes (each with single species in single family) (Table 1). Goyal et al. (2014) also reported 64 migratory avian species comprising 44 genera, 27 families and 9 orders in Ottu Lake, Sirsa, Haryana. In accordance with previous records such as avifauna of Sultanpur National Park, Haryana (Chopra et al.,2012); 


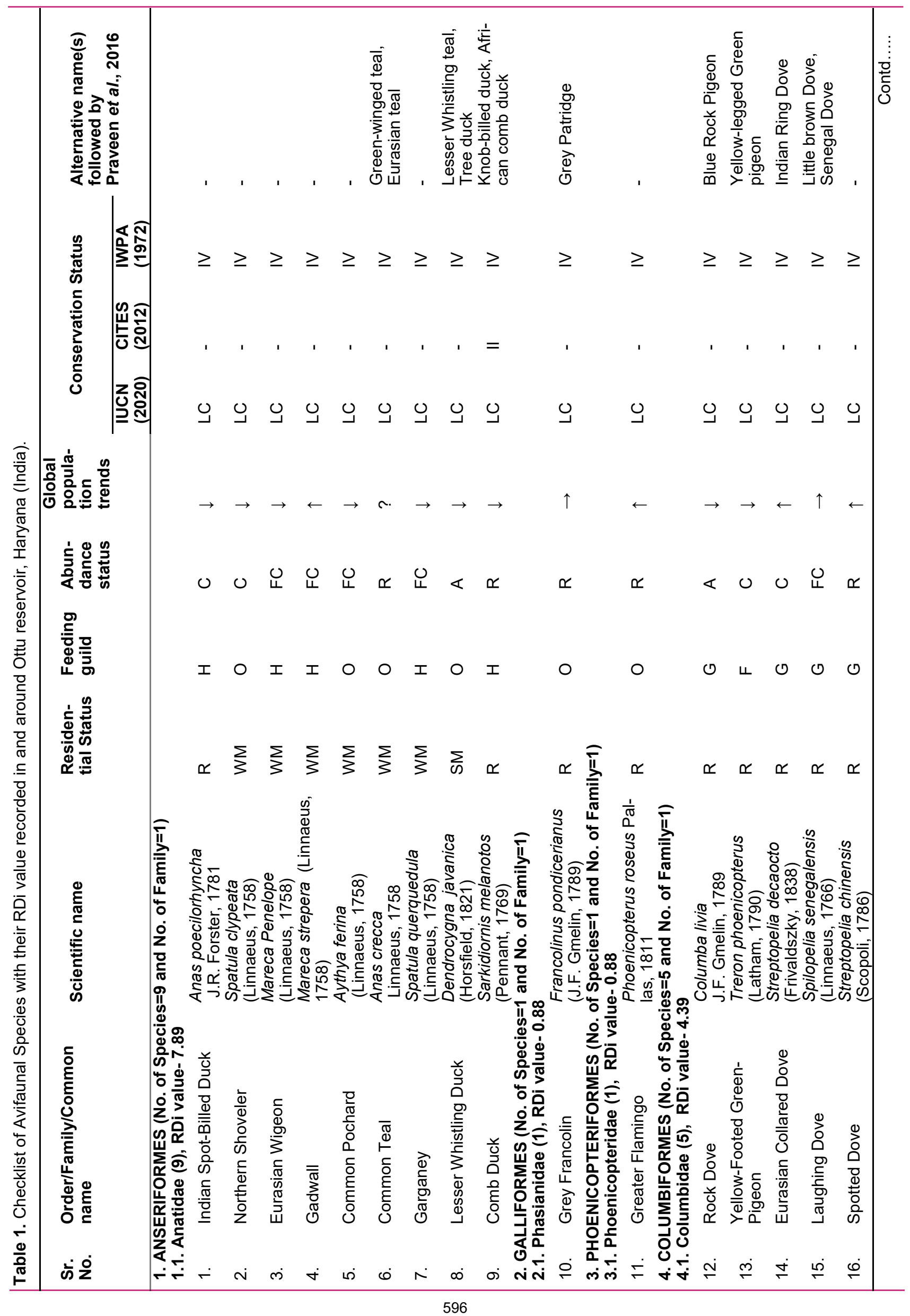




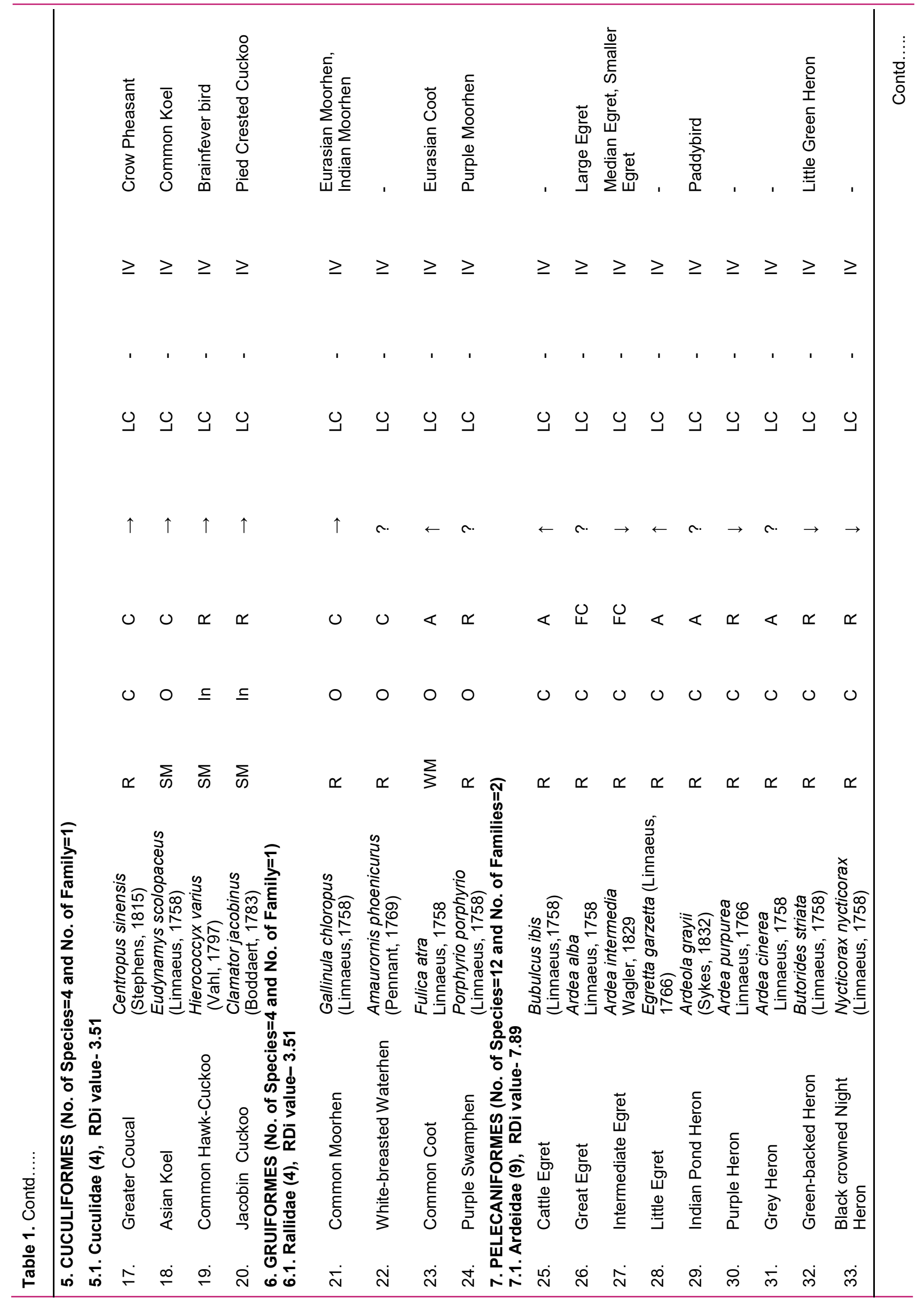




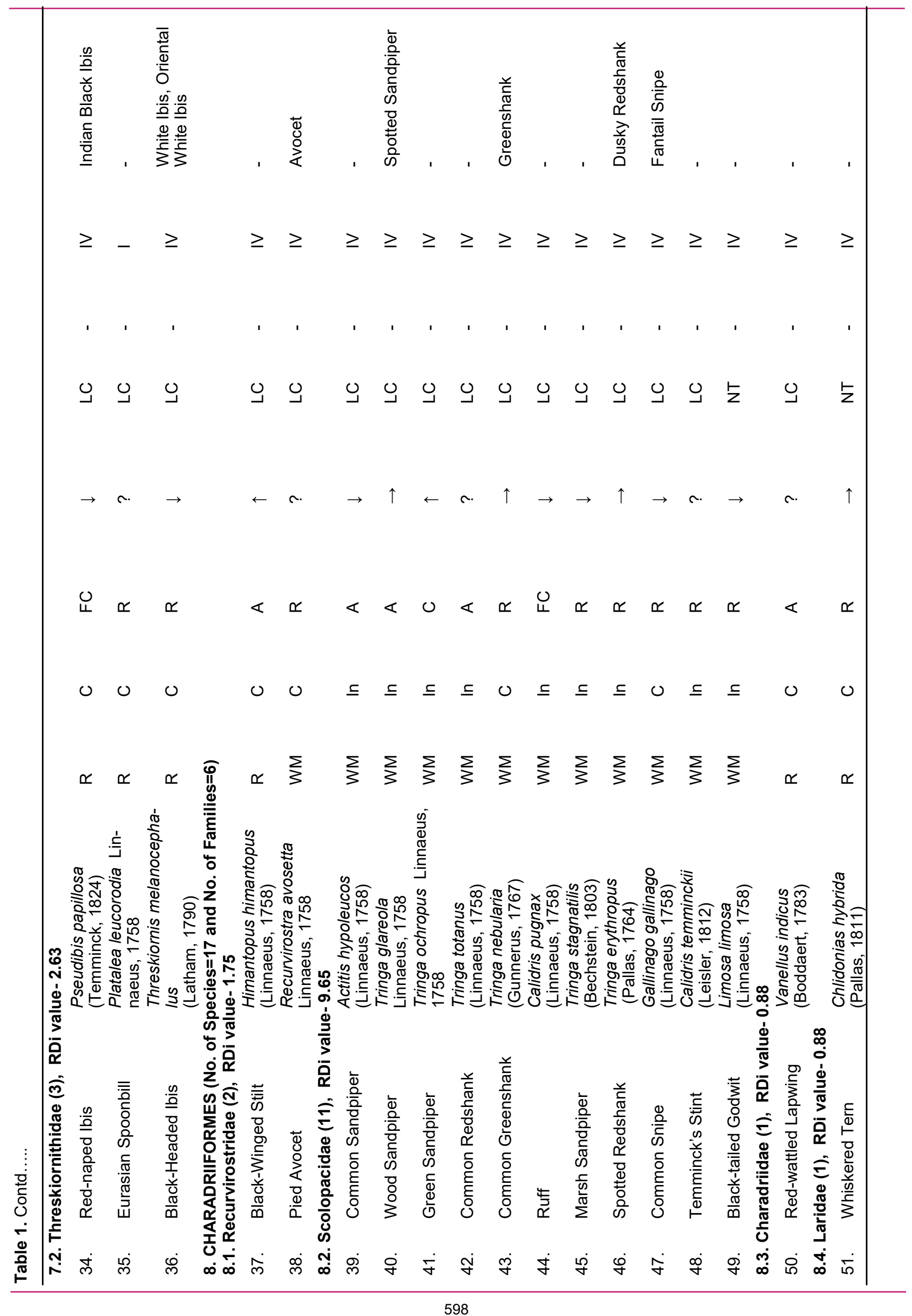




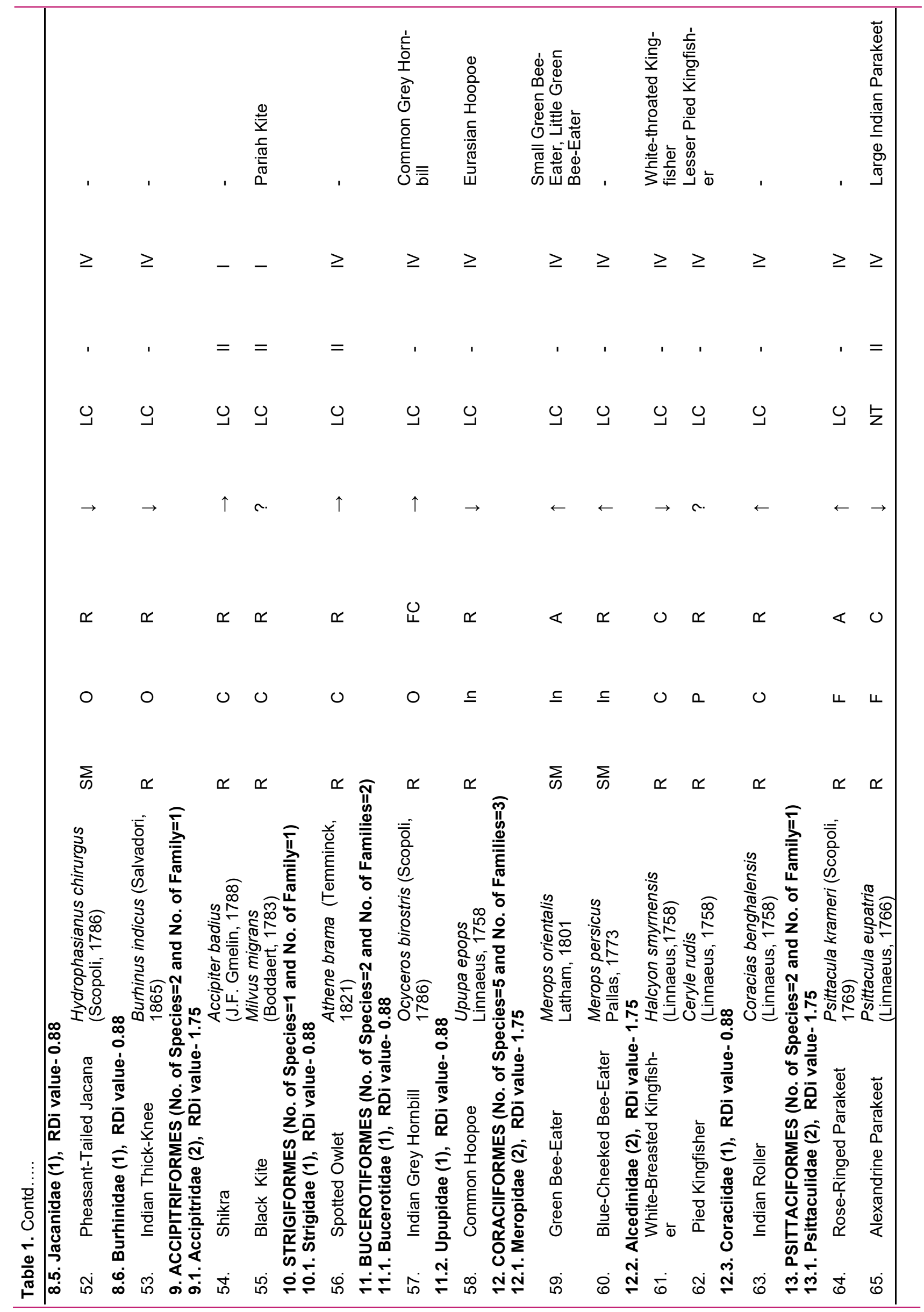




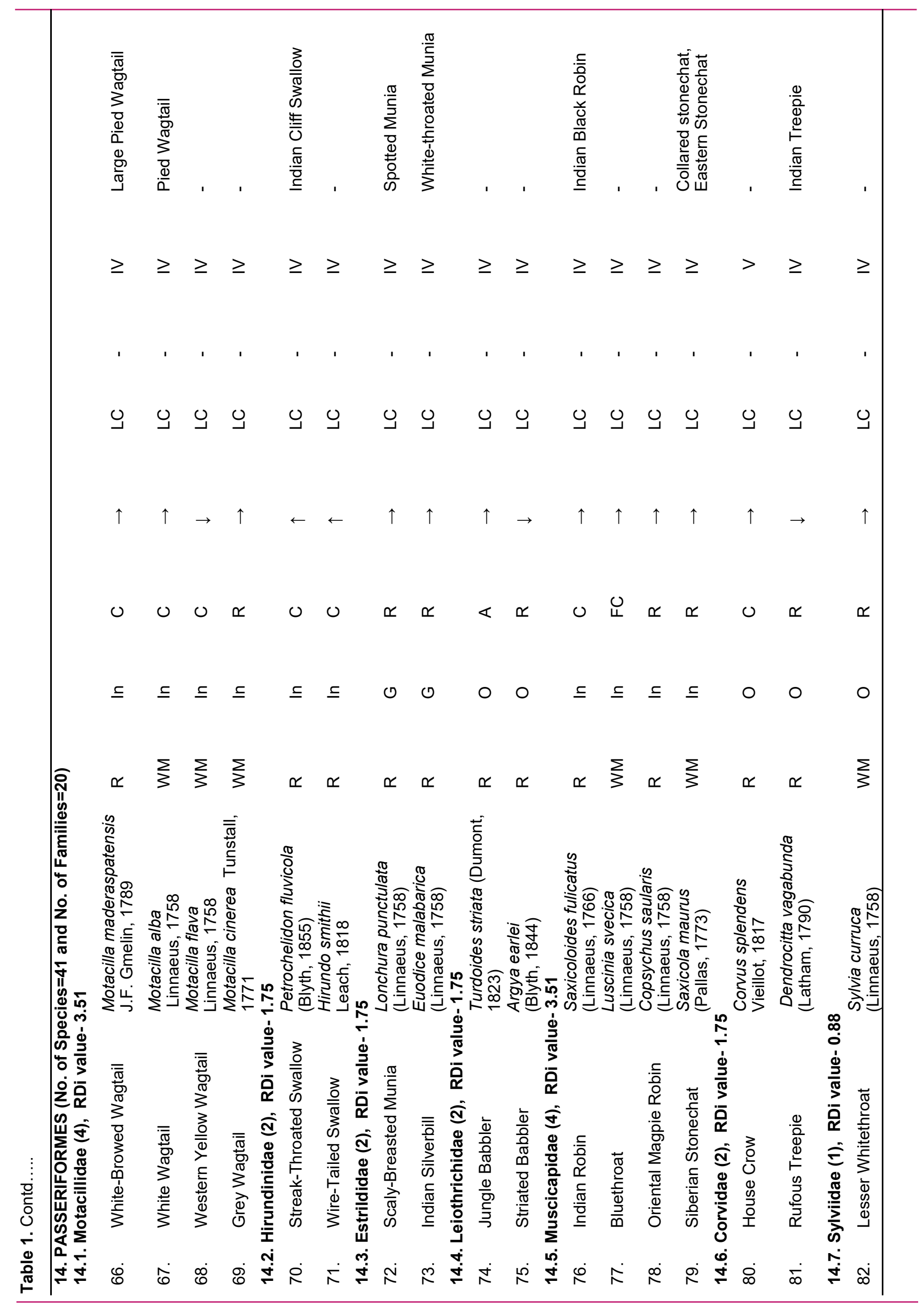




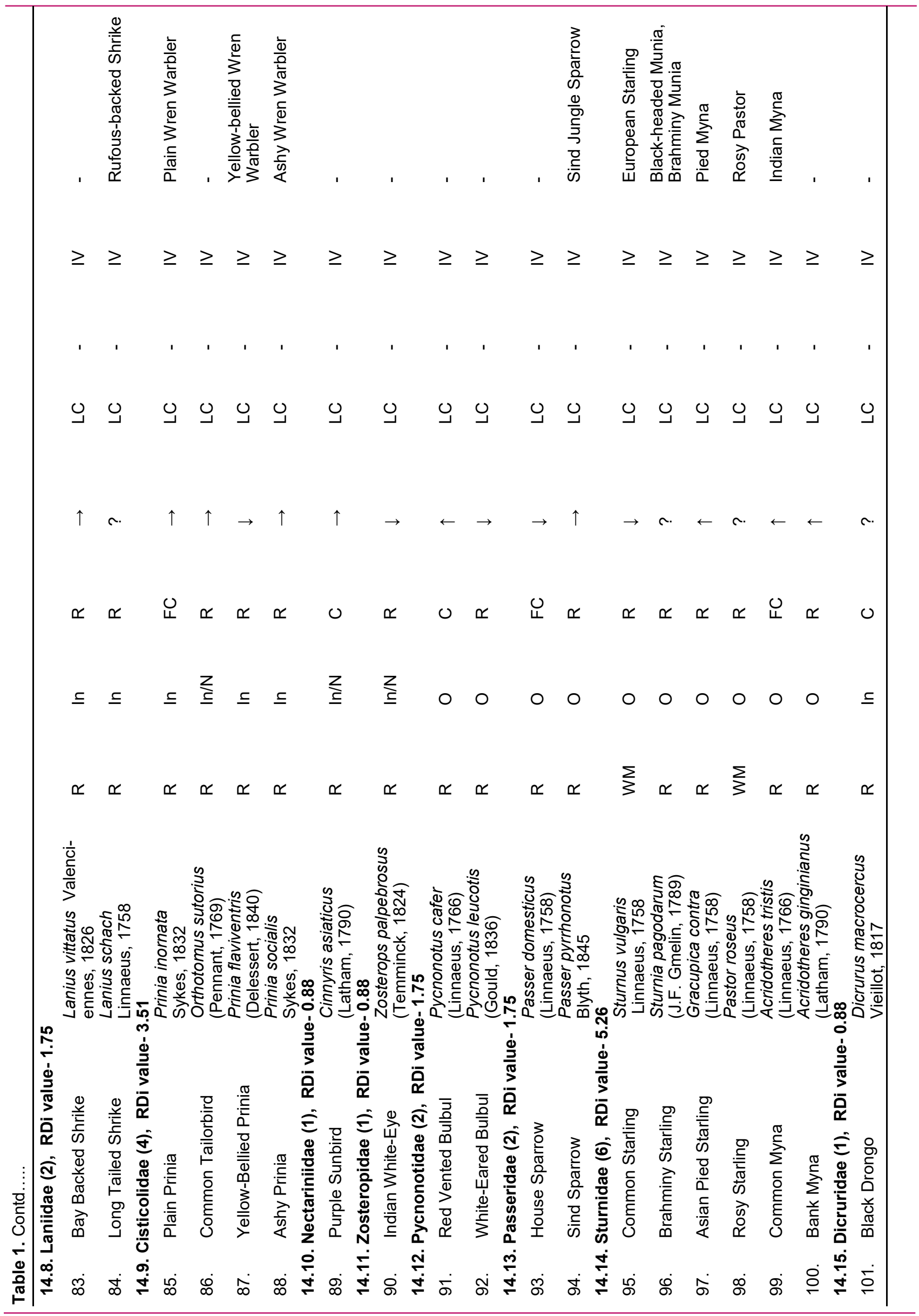




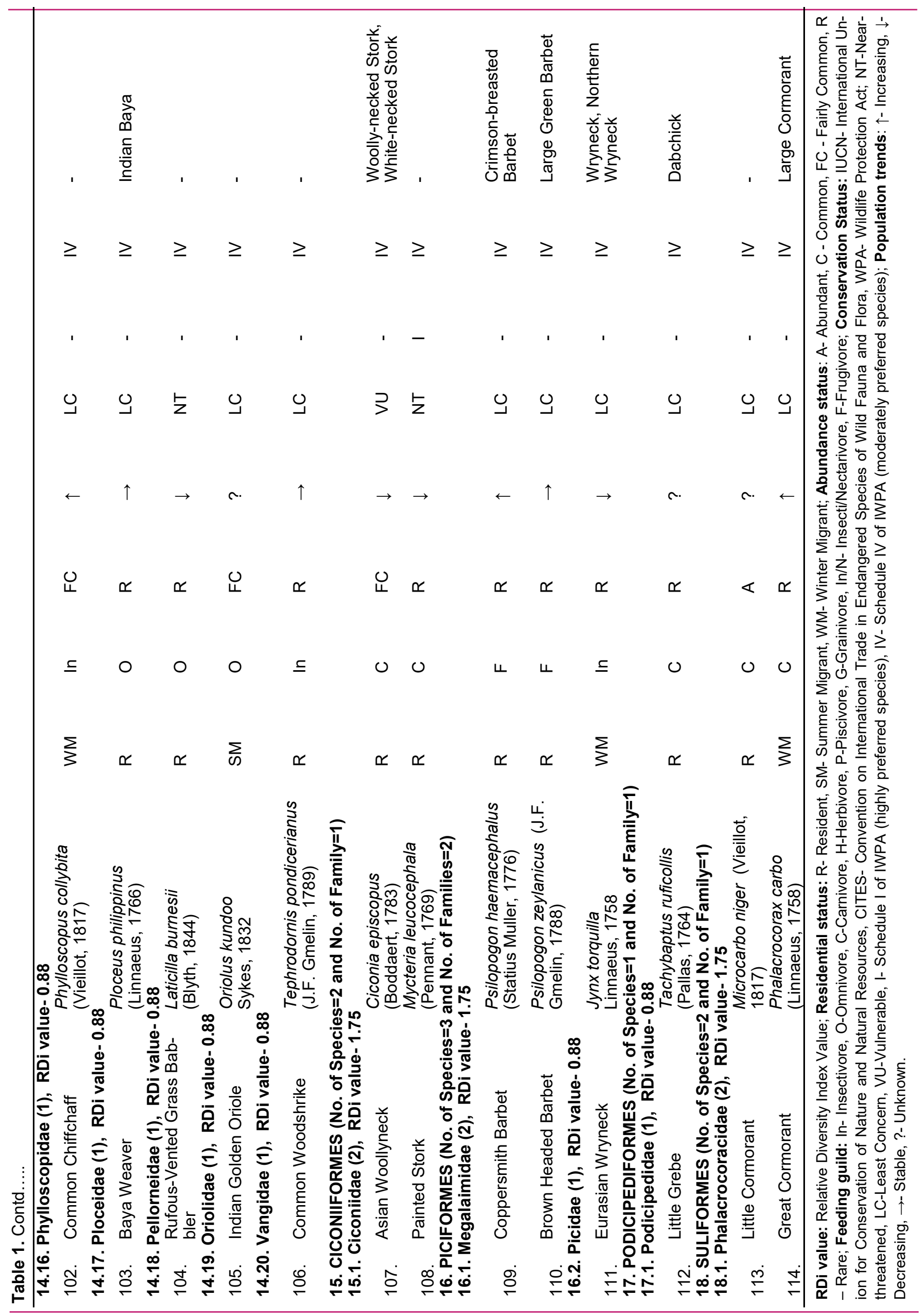


Kalesar National Park, Haryana (Rai et al., 2017b); Gibe Sheleko National Park, South-western Ethiopia (Desta et al., 2020); Sheikh Badin National Park, Khyber (Ullah et al., 2021), order Passeriformes was the most prevalent taxa of avifauna in different areas. Due to their ability to use a wide range of habitats and consume varied food items such as grains, nuts, floral buds, fruits, nectar and invertebrates, passerines species encompasses high diversity in an area (Beresford et al., 2005). Analysis of RDi (Relative diversity) results revealed Scolopacidae as a highly diverse family possessing 11 species and the greatest RDi value, i.e., 9.65 , in contrast to other families. The presence of food in large quantities plays a crucial role in revealing the existence of specific species in an area. The result of feeding guild of observed species revealed Carnivores (35 species) as highly dominated guild followed by Insectivores (32 species); Omnivores (26 species); Grainivores (6 species); Herbivores (6 species); Frugivores (5 species); Insecti/Nectarivores (3 species) and Piscivores (one species). The maximum number of carnivorous bird species represents that the lake provides enormous food assets in terms of amphibians, crustaceans, fishes, reptiles and another non-insect invertebrate as well as vertebrates species (Kumar and Gupta, 2013; Jamwal et al., 2017; Kumar and Sharma, 2018; Sohil and Sharma, 2020). Out of recorded 114 species, 76 species were Resident; 30 Winter migrants and 8 summer migrants (Table 1). Some of the migratory species were Eurasian wigeon Mareca Penelope; Marsh Sandpiper Tringa stagnatilis; Spotted Redshank Tringa erythropus; Common Snipe Gallinago gallinago; Rosy Starling Pastor roseus,; Black Tailed Godwit Limosa limosa; Grey Wagtail Motacilla cinerea; Lesser Whitethroat Sylvia curruca; Great Cormorant Phalacrocorax carbo; Common Hawk cuckoo Hierococcyx varius; Pheasant-tailed Jacana Hydrophasianus chirurgus. Earlier record in Ottu Lake, Sirsa, Haryana documented 64 migratory species constituting 57 winter migrants and 7 summer migrant (Goyal et al. 2014). Studies such as Rai et al. (2017a) on Basai wetland; Chopra et al. (2017) on Bhindawas bird sanctuary; Rai et al. (2019) on Basai wetland; Vishwakarama et al. (2020) on Kopra reservoir revealed the presence of a maximum number of migratory birds in winter season in accordance with other respective seasons. Kumar et al. (2016) also recorded highest number of winter migratory species from Rural ponds of Kurukshetra, Haryana, being the presence of their study site on Central Asian Flyway. Being located on CAF (Central Asian Flyway) selected study site Ottu Reservoir, Sirsa also serves as most preferred wintering area for migrant avifaunal diversity that breeds in Palaearctic region of biogeographic realms.

On the basis of IUCN Red list Criteria, 107 species were observed as Least concern (LC); six were Near threatened (NT) and the single species as Vulnerable (VU). Species such as Black-Tailed Godwit Limosa limosa; Black-Headed Ibis Threskiornis melanocephaIus; Alexandrine Parakeet Psittacula eupatria; Whiskered Tern Chlidonias hybrida; Rufous-Vented GrassBabbler Laticilla burnesii; Painted Stork Mycteria leuco-

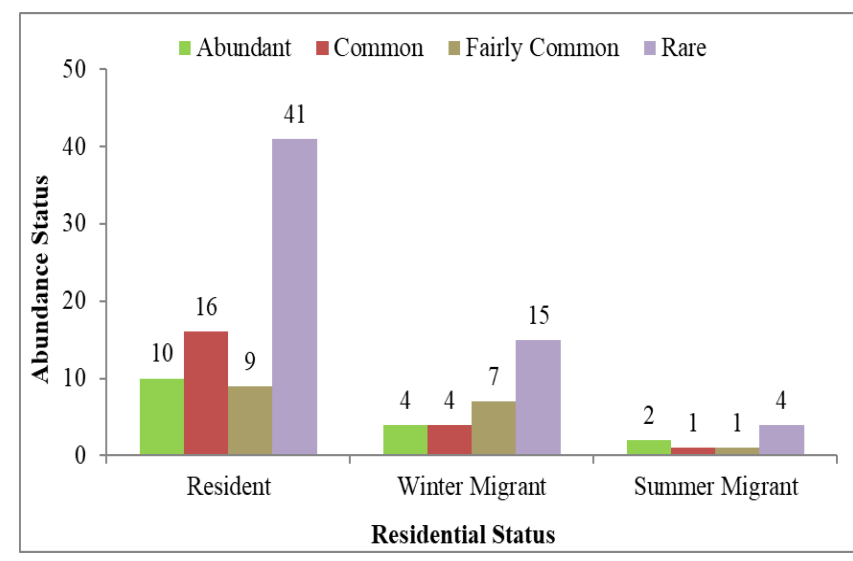

Fig. 3. Comparison of residential status and abundance status of species recorded in and around Ottu reservoir, District Sirsa, Haryana (India).

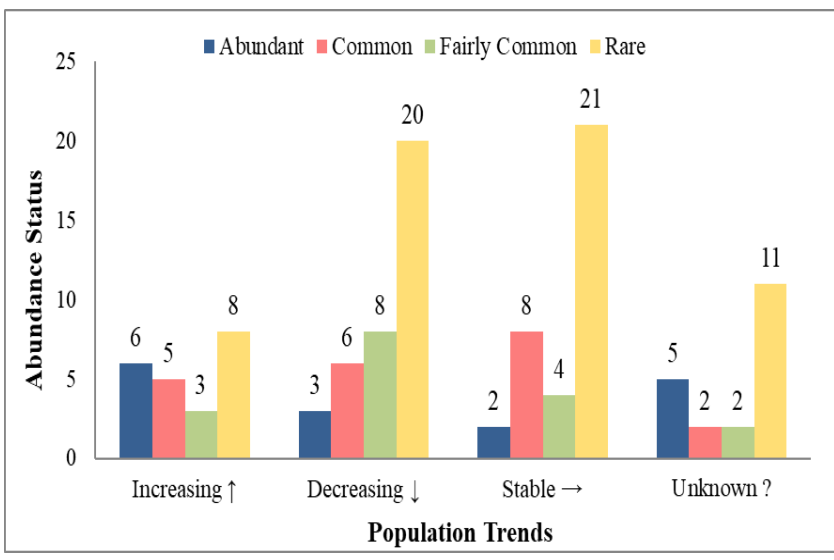

Fig. 4. Relationship between population trends and abundance status of species documented in and around Ottu reservoir, District Sirsa, Haryana (India).

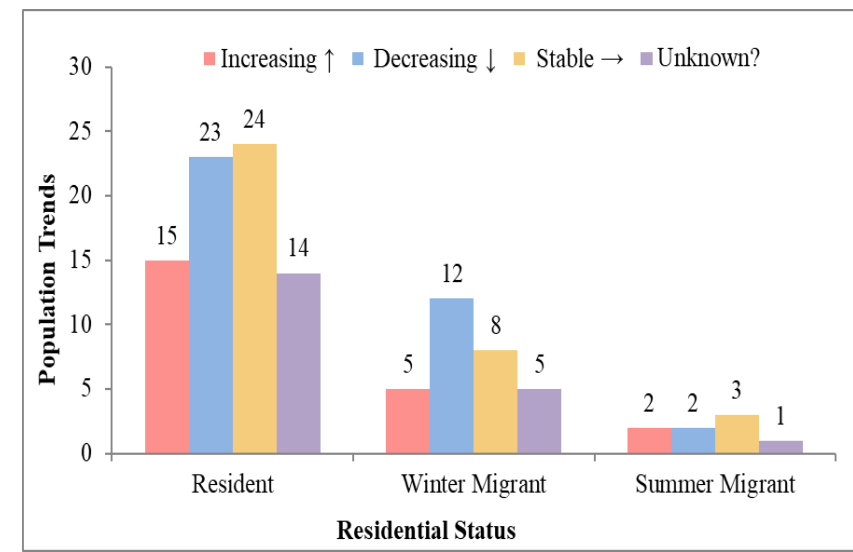

Fig. 5. Relationship between residential status and population trends of species recorded in and around Ottu reservoir, District Sirsa, Haryana (India). 
cephala were Near-Threatened (NT) whereas Asian Woollyneck Ciconia episcopus was Vulnerable (VU). Three species such as Shikra Accipiter badius, Black kite Milvus migrans and Eurasian Spoonbill Platalea leucorodia were documented under Schedule-I and the remaining 111 species under Schedule-IV of Wildlife Protection Act (IWPA,1972). Six species from the reported avian species fall under various categories of CITES (2012) presenting Appendix-II (i.e. includes five species) and Appendix-I (i.e. include single species), respectively. In the present study, Rufous-Vented Grass-Babbler Laticilla burnesii was also recorded by us during one year study period in the study area as well as by others in district sirsa claiming its last sighting in October 2003 (Prayag Arora- Desai, 2019). Data on the abundance status of reported (residential and migratory) species figured out that 16 species were abundant, 21 were common, 17 were fairly common and 60 were rare in the area. The abundance status of a species in a region is determined by the composition of the vegetation that forms a major component of the habitat (Block and Brennan, 1993). A comparison of residential status of observed species with abundance status revealed that of 76 resident species, 10 species were abundant, 16 commons, 9 fairly common and 41 rare; among 30 winter migrants: 4 species were abundant, 4 common, 7 fairly common and 15 rare and of 8 Summer migrants: 2 species abundant, 1 common, 1 fairly common and 4 rare (Fig. 3). Depending on the abundance status, appropriate conservation planning is essential for maintaining these rare species' diversity in the study area. The population trends consigned in accordance with IUCN Red List (IUCN, 2020) revealed that among recorded avian fauna, increasing trends were by 22 species; decreasing by 37 species; stable by 35 species and unknown by 20 species. A comparison between local abundance status and population trends (Fig. 4) described three species namely Rock dove Columba livia, Lesser Whistling-duck Dendrocygna javanica and Common Sandpiper Actitis hypoleucos with decreasing global population trends of IUCN, were present abundantly in the reservoir, due to presence of suitable food resources and appropriate environmental conditions. Similarly, analysis of global IUCN population trends with respect to the residential status of bird's results out that among 76 residents species: 15 species shows increasing trend $(\uparrow), 23$ species decreasing trend $(\downarrow), 24$ species stable trend $(\rightarrow)$ and 14 species unknown trend (?); whereas of 30 winter migrants: 5 species with an increasing trend $(\uparrow), 12$ species decreasing trend $(\downarrow), 8$ species stable trend $(\rightarrow)$ and 5 species unknown trend (?) and of 8 summer migrants: 2 species shows increasing trend $(\uparrow), 2$ species decreasing trend $(\downarrow), 3$ species stable trend $(\rightarrow)$ and single species with unknown status (Fig. 5). Concerning conservation, species with decreasing IUCN population trends need to be prioritized for extensive monitoring and other threatened species. A proper management plan should be made at objective and secondary levels, emphasizing wetland protection and sustainable use, as the lake is home to a huge number of bird species.

\section{Conclusion}

The present study provides information about the ecological characteristics of Ottu reservoir, which serves as heaven for 114 avian species (18 orders, 47 families and 91 genera), sustaining serenity, contiguity of river, diverse habitat, vast aquatic area, agricultural fields, nutrient-rich water and other environmental conditions. Recorded data of 114 bird species at the reservoir can be used as baseline data for assessing future perspectives and proper management plans for wetland protection and its sustainable use. Long-term monitoring of avifaunal composition in this area will act as excellent means to determine the effects of anthropogenic pressures and implement conservation strategies of the Ottu reservoir, Sirsa (Haryana).

\section{ACKNOWLEDGEMENTS}

Our sincere thanks to the Department of Zoology, Kurukshetra University, Kurukshetra, for providing the requisite facilities. We are thankful to the CSIR for awarding the JRF Fellowship for this research.

\section{Conflict of interest}

The authors declare that they have no conflict of interest.

\section{REFERENCES}

1. Akosim, C., Isa, M., Ali, A. \& Kwaga, T. (2008). Species absolute population density and diversity of water birds in wetland areas of Yankari National Park, Bauchi State Nigeria. Environmental Research Journal, 2(1), 28-32

2. Ali, S. \& Ripley. S.D. (1987). Compact handbook of the birds of India and Pakistan. Oxford University Press, New Delhi.

3. Altmann, J. (1974). Observational study of behavior: sampling methods. Behaviour, 49, 227-267

4. Arlott, N. (2015). Birds of India, Pakistan, Nepal, Bhutan, Bangladesh, and Srilanka. William Collins Publishers, London.

5. Basu, P.S., Sao, S. \& Singh, R.K. (2018). Diversity, seasonal variation, abundance and migratory behavior of local and migratory water birds of Mukutmanipur dam, Bankura, West Bengal, India. World Journal of Pharmaceutical Research, 7(11), 855-869

6. Beresford, P., Barker, F.K., Ryan, P.G. \& Crowe, T.M. (2005). African endemics span the tree of songbirds (Passeriformes): molecular systematic of several evolutionary "enigmas". Proceedings of the Royal Society B: Biological Sciences, 272, 849-858 https://doi.org/10.1098/ rspb.2004.2997

7. Blair, R. B. (1999). Birds and butterflies along an urban gradient. Surrogate taxa for assessing biodiversity. Eco- 
Rai, D. and Vanita / J. Appl. \& Nat. Sci. 13(2), 593 - 606 (2021)

logical Applications, 9, 164-170

8. Block, W.M. \& Brennan, L.A. (1993). The habitat concept in ornithology: Theory and applications. Current Ornithology, 11, 35-91

9. Chopra, G., Tyor, A.K., Kumari, S. \& Rai, D. (2012). Status and conservation of avian fauna of Sultanpur National Park Gurgaon, Haryana (India). Journal of Applied and Natural Science, 4(2), 207-213

10. Chopra, G. \& Jakhar, P. (2016). Avian Diversity of Wetland Habitats of District Fatehabad, Haryana (India). International Journal of Pharmacy and Life Sciences, 7(9), 5185-5199

11. Chopra, G., Rai, D. \& Jyoti. (2017). Avian diversity and their status in and around Bhindawas bird sanctuary, Haryana (India). Journal of Applied and Natural Science, 9(3), 1475- 1481 https://doi.org/10.31018/jans.v9i3.1387

12. CITES (2012). Checklist of Conventon on Internatonal Trade in Endangered Species of Wild Fauna \& Flora. CITES, Geneva, Switzerland. Downloaded on 06 April 2021; http://www.cites.org

13. Desta, H.T., Bekele,A., Wagaw, S. \& Admasu, S. (2020). Assessment of avifaunal assemblage and their distribution pattern across different habitat types of Gibe Sheleko National Park, South-western Ethiopia. International Journal of Biodiversity and Conservation, 12(1), 59-70 https:/ doi.org/10.5897//JBC2019.1380

14. Gaston, A.J. (1975). Methods for estimating bird population. The Journal of the Bombay Natural History Society. 69(3), 591-615

15. Gopal, B. \& Sah, M. (1993). Conservation and management of rivers in India: case-study of the river Yamuna. Environmental Conservation, 20(3), 243-254

16. Goyal, V., Singh, V., Devi, P. \& Malik, V. (2014). Diversity of migratory birds in Ottu Reservoir, Sirsa, Haryana, India. Journal of Experimental Zoology, India, 17(2), 507-512

17. Goyal, V., Singh, V. and Malik, V. (2016). Diversity indices of passerine birds of district Sirsa, Haryana, India. Journal of Environment and Bio-Science, 30(1), 117122

18. Grimmett, R., Inskipp, C. \& Inskipp, T. (1999). Pocket Guide to the Birds of the Indian Subcontinent. Oxford University Press, New Delhi, India, $384 \mathrm{pp}$

19. Grimmett, R., \& Inskipp, T. (2003). Birds of Northern India. Oxford University Press, New Delhi.

20. Grimmett, R. \& Inskipp, T. (2019). Birds of Northern India. Christopher Helm London.

21. Grimmett, R., Inskipp, C. \& Inskipp, T. (2015). Birds of Indian Subcontinent. $2^{\text {nd }}$ Edition. Oxford University Press, India.

22. Gupta, R.C. \& Kaushik, T.K. (2013). Rich winter migratory birds in thousands have become victim of Kurukshetra utsav in Haryana, India. International Journal of Life Science, 7(1), 6-11 https://doi.org/10.3126/ijls.v7i1.7962

23. Harisha, M.N. \& Hosetti, B.B. (2018). Status and conservaton issues of wetland birds in Komaranahalli Lake, Davanagere District, Karnataka, India. Journal of Threatened Taxa, 10(2), 11290-11294 https://doi.org/10.11609/ jot.2809.10.2.11290-11294

24. IUCN (2020). The IUCN Red List of Threatened Species. Version 2020-2. Downloaded from http://www.iucnre dlist.org.

25. IWPA (1972). https://www.wiienvis.nic.in/Database/
ScheduleSpeciesDatabase_7969.aspx (update dt. 28/4/ 2014).

26. James, C.S., Birkhead, A.L., Jordanova, A.A., Kotschy, K.A. \& Nicolson, C.R. (2001). Interaction of Reeds, Hydraulics and River Morphology, Report 856/1/01. Water Research Commission, South Africa.

27. Jamwal, P.S.,Chandan, P., Rattan, R., Anand,A., Kannan, P.M. \& Parsons, M.H. (2017). Survey of avifauna of the Gharana wetl and reserve: implications for conservation in a semi-arid agricultural setting on the Indo-Pakistan border. BMC Zoology, 2, 7 https://doi.org/10.1186/s40850017-0016-z

28. Kalsi, R.S., Sharma, S.C. \& Choudhary, J.R. (2019). Birds of Haryana- A Field Guide. Unique Publications, Haryana, India.

29. Kumar, P. \& Gupta, S.K. (2009). Diversity and Abundance of Wetland Birds around Kurukshetra, India. Our Nature, 7, 212-217 https://doi.org/10.3126/on.v7i1.2574

30. Kumar, P. \& Gupta, S.K. (2013). Status of wetland birds of Chhilchhila Wildlife Sanctuary, Haryana, India. Journal of Threatened Taxa, 5(5), 3469-3976 https://doi.org/10.116 09/JoTT.03158.3969-76

31. Kumar, P., Rai, D. \& Gupta, S.K. (2016). Wetland bird assemblage in rural ponds of Kurukshetra, India. Waterbirds, 39(1), 86-98 https://doi.org/10.1675/063.039.0111

32. Kumar, P. \& Sharma, A. (2018). Diversity and status of avifauna in man-made sacred ponds of Kurukshetra, India. Journal of Threatened Taxa, 10(9), 12173-12193 https://doi.org/10.11609/jot.3729.10.9.12173-12193

33. Kumar, P. \& Sahu, S. (2020). Compositon, diversity and foraging guilds of avifauna in agricultural landscapes In Panipat, Haryana, India. Journal of Threatened Taxa, 12 (1), 15140-15153 https://doi.org/10.11609/jot.5267.12.1.1 5140-15153

34. La Torre-Cuadros, M.A., Herrando-Perez, S. \& Young, K.R. (2007). Diversity and structure patterns for tropical montane and premontane forests of central Peru, with an assessment of the use of higher-taxon surrogacy. Biodiversity and Conservation, 16, 2965-2988 https:// doi.org/10.1007/s10531-007-9155-9

35. National Wetland Atlas (2011). National Wetland Atlas, SAC/EPSA/ABHG/NWIA/ATLAS/34/2011. Space Applications Centre (ISRO), Ahmedabad, India, 310pp.

36. Newton, L. \& Anim, M. (1995). The contribution of some recent research on birds to Ecological understanding. Journal of Animal Ecology, 64, 675-696

37. Niemi, G.J. (1985). Patterns of morphological evolution in bird genera of New World and Old World Peatland. Ecology, 66, 1215-1228

38. Padmavathy, A., Alexandar, R. \& Anbarashan, M. (2010). Diversity of Birds in Ousteri Wetland, Puducherry, India. Our Nature, 8, 247-253

39. Pawar, R.T., Pathan, T.S. \& Bhosale, Y.M. (2019). Avifaunal study of Majalgaon Reservoir and their tributaries, District Beed, Marathwada region of Maharashtra, India. International Journal of Scientific Research in Biological Science, 6(4), 51-55 https://doi.org/10.26438/ijsrbs/v6i4.5 15.

40. Praveen, J., Jayapal, R. \& Pittie, A. (2016). A checklist of the Birds of India. Indian Birds, 11(5\&6), 113-172

41. Praveen J., Jayapal, R., Inskipp, T., Warakagoda, D., Thompson, P.M., Anderson, R.C. and Pittie, A. (2019), 
Checklist of the birds of the Indian subcontinent (v3.0) Website: http://www.indianbirds.in/indian-subcontinent/ [Date of publication: 05 May, 2019].

42. Prayag Arora-Desai (2019). Rufous-vented grass babblers spotted in Sirsa. Hindustan Times, Published on Nov 13, 2019. Retrived from https://www.hindustantimes.com/ cities/rufous-vented-grass-babblers-spotted-in-sirsa/storyzy8mtnTsLIkdlArqNZVyhl.html.

43. Rai, D., Chopra, G., Gulia, R. \& Vats, P. (2017). Avian diversity of Basai Wetlands, Haryana (India): An IBA site. Journal of Experimental Zoology, India, 20(1), 109- 117

44. Rai, D., Chopra, G. \& Gulia, R. (2017a). Status of migratory avifaunal diversity of Basai wetlands, Haryana (India). Journal of Experimental Zoology India, 20(2), 981-985

45. Rai, D., Vats, P. \& Gulia, R. (2017b). Avifaunal status of Kalesar National Park, Haryana (India). Journal of Experimental Zoology India, 20(2), 827-833

46. Rai, D., Gulia, R., Chopra, G. \& Kumar, P. (2019). Avifaunal Community Composition and Current Status in Basai Wetlands: An important bird Area in Haryana, India. Indian Forester, 145(10), 971-985

47. Singh, J., S. Antil, V. Goyal \& V. Malik (2020). Avifaunal diversity of Tilyar Lake, Rohtak, Haryana, India. Journal of Threatened Taxa, 12(8), 15909-15915 https:// doi.org/10.11609/jot.4700.12.8.15909-15915
48. Sohil, A. \& Sharma, N. (2020). Bird diversity and distribution in mosaic landscapes around Jammu, Jammu and Kashmir. Acta Ecologica Sinica, https://doi.org/10.1016/ j.chnaes.2020.02.005

49. State of India's Birds (2020). Range, trends and conservation status. The SolB Partnership. Pp 50. www.stateof indiabirds.in

50. Sutherland, W.J., Newton, I. \& Green, R.E. (2005). Bird Ecology and Conservation: $A$ handbook of Techniques. Oxford University Press.

51. Ullah., Qing-Ming, W.U., Xue-Ying, S., Khan, M.S., Ullah, S., Khan, T.U. \& Nawaz, R.M. (2021). Diversity, Abundance, Status And Endangered Habitats Of Avifauna In Sheikh Badin National Park, Dera Ismail Khan, Khyber. The Journal of Animal \& Plant Sciences, 31(1), 307-316 https://doi.org/10.36899/JAPS.2021.1.0218

52. Vishwakarma, A., Anthony, F.M., Tiwari, S. \& Choubey, S. (2020). Avifaunal Diversity of Winter Season in Kopra Reservoir of Bilaspur, Chhattisgarh, India. Proceedings of the Zoological Society. https://doi.org/10.1007/s12595-020 $-00349-z$

53. Whelan, C.J., Sekerciog $` u$, C.H. \& Wenny, D.G. (2015). Why birds matter: from economic ornithology to ecosystem services. Journal of Ornithology, 156 (Suppl 1), S227 -S238 10.1007/s10336-015-1229-y 